\title{
Acil Uzaktan Eğitim Sürecinin Analizi: Öne Çıkan Kavramlar, Sorunlar ve Çıkarılan Dersler ${ }^{1}$
}

\author{
Sezan SEZGiN ${ }^{2}$
}

Başvuru Tarihi: 13.01 .2021

Kabul Tarihi: 21.02 .2021

Makale Türü: Araştırma Makalesi

\section{Öz}

COVID-19 pandemi süreciyle birlikte, dünya üzerinde tüm yaş gruplarından yaklaşık bir buçuk milyar öğrenci yüz yüze eğitimden uzaktan eğitim faaliyetlerine geçiş yapmıştır. Acil uzaktan eğitim (AUE) olarak adlandırılan bu eğitsel tepki, pandemi sürecinin getirdiği eğitsel olumsuzluklara hızlı ve olumlu bir cevap vermiștir. Eğitimciler için, AUE süreçlerindeki paydaş deneyimleri ve gerçekleştirilen uygulamaların doğru yorumlanmasl, pandeminin olası ilerleyen dönemlerinde veya pandemi sonrası için sürdürülebilir ve planlı uzaktan eğitim faaliyetlerinin gerçekleştirilebilmesi bağlamında kritik öneme sahiptir. Bu çalışmada COVID-19 pandemi sürecinde dünya genelinde yapılmış AUE araştırmaları içeriksel olarak analiz edilmiş, AUE sürecinde bazı betimsel-tanımlayıcı veriler, öne çıkan kavramlar, sorunlar, ve çözüm önerileri incelenmiştir. Araştırma kapsamında bilimsel makaleler, tam metin bildiriler ve bilimsel kitap bölümlerinden faydalanılmış, verilerin yorumlanması aşamasında gri literatürden de faydalanılmıştır. Araştırmada analiz edilen çalışmalar; SCOPUS, Web of Science, Science Direct, Emerald Insight, IEEE Xplore, ACM Digital Library, EBSCO host research databases (Academic Search Premier, H.W. Wilson, British Education Index, ERIC vb.), JSTOR ve Google Akademik veri tabanları aracıllğıyla toplanmıştır. Araştırma kapsamında toplamda 2535 araştırmaya ulaşılmış, bunlarm 252'si detayl incelenerek 152'si analize dahil edilmiştir. Analiz sürecinde tematik analiz ve betimsel analizden yararlanılmıştır. Pandemi dönemi AUE sürecinde öne çıkan kavramlar beş, yaşanan sorun ve kısıtlar on bir ve çözüm önerileri ise altı anatema altında kategorilendirilmiştir. Araştırma bulguları, pandemi döneminde AUE konu alanında gerçekleştirilen çalışmaların çoğunlukla yükseköğretim alanında ve genellikle gelişmiş ülkelerde yapıldığını göstermektedir. Bununla beraber dijital uçurumun öne çıkan kavram ve sorunlar başlıklarında öne çıkan gerçeklik olduğu görülmektedir. Çalışma sonucunda, araştırma kapsamında elde edilen bulgular dahilinde, planlı uzaktan eğitim faaliyetleri için farklı kategori ve içeriklerle ilgili önerilerde bulunulmuştur.

Anahtar Kelimeler: Acil Uzaktan Eğitim, Açık ve Uzaktan Eğitim, COVID-19 Sürecinde Eğitim, Dijital Uçurum, Dijital Yeterlilikler

Atıf: Sezgin, S. (2021). Acil uzaktan eğitim sürecinin analizi: Öne çıkan kavramlar, sorunlar ve çıkarılan dersler. Anadolu Üniversitesi Sosyal Bilimler Dergisi, 21(1), 273-296.

\footnotetext{
Bu çalışma etik kurul izin belgesi gerektirmemektedir.

2 Burdur Mehmet Akif Ersoy Üniversitesi Eğitim Fakültesi Bilgisayar ve Öğretim Teknolojileri Ĕ̆itimi, sezansezgin@mehmetakif.edu.tr, ORCID: 0000-0002-2068-2841
} 


\title{
AÜSBD Anadolu Üniversitesi Sosyal Bilimler Dergisi Anadolu University Journal of Social Sciences
}

\section{Analysis of the Emergency Remote Education Process: Featured Terms, Problems and Lessons Learned}

\author{
Sezan SEZGiN ${ }^{3}$
}

Submitted by: 13.01 .2021

Accepted by: 21.02.2021

Article Type: Research Article

\begin{abstract}
With the beginning of the COVID-19 pandemic process, approximately one and a half billion students from all age groups around the world have switched from face to face education to distance education activities. This educational response, called emergency remote education (ERE), has given a quick and positive response to the educational negativity brought about by the pandemic. For educators, stakeholder experiences in ERE processes and accurate interpretation of the practices carried out are critical in the context of sustainable and planned distance education activities for the possible later stages of pandemic or after pandemic. In this study, ERE research conducted worldwide during the COVID-19 pandemic process was analyzed contentwise and some descriptive data, prominent concepts, problems and solution proposals were examined in the ERE process. Within the scope of the research, gray literature was also used in the interpretation of the data used in scientific articles, full text conference papers and scientific book chapters. Studies analyzed in the study were gathered from; SCOPUS, Web of Science, Science Direct, Emerald Insight, IEEEXplore, ACM Digital Library, EBSCO host research databases (including Academic Search Premier, H.W. Wilson, British Education Index, ERIC et al.), JSTOR and Google Scholar databases. A total of 2535 researches were reached within the scope of the study, 252 of which were examined in detail and 152 were included in the analysis phase. Thematic analysis and descriptive analysis were used during the analysis process. The concepts that stand out in the pandemic ERE period are categorized under five, the problems \& constraints experienced are categorized under eleven and solution proposals are categorized under six main themes. Research findings show that studies conducted in the field of ERE during pandemic were mostly conducted in the field of higher education and often in developed countries. However, it is seen that the digital divide is the reality that stands out in the context of the concepts emerged and problems experienced. As a result of the study, recommendations were made about different categories and content for planned distance education activities within the scope of the findings obtained within this research.
\end{abstract}

Keywords: Emergency Remote Education, Open and Distance Education, Education in the COVID-19 Period, Digital Divide, Digital Competencies

3 Burdur Mehmet Akif Ersoy University Faculty of Education Computer and Instructional Technologies Department, sezansezgin@mehmetakif.edu.tr, ORCID: 0000-0002-2068-2841 


\section{Giriş}

Güney Asya’ da 2019’ un sonlarında hızla yayılarak salgına dönüşen yeni tip koronavirüsün etkileri hızla tüm dünyada yayılmış, salgın Dünya Sağlık Örgütü (DSÖ) tarafından Mart 2020' de küresel bir pandemi olarak ilan edilmiştir. 21. yüzyılda, birçok teknolojik araç, donanım ve dijital yapı ile beraber, teknolojik gelişmişlik bakımından kendisini oldukça ileri bir seviyede gören ve tanımlayabilen insanlık, COVID-19 pandemisi olarak ilan edilen (DSÖ, 2020) salgın karşısında, içinde bulunduğu zaman dilimi içerisinde kitlesel olarak çaresiz kalmıştır. Salgının etkilerini kontrol altında tutabilmek için birçok ülke daha önce görülmemiş katı önlemler almaya çalışmış, ekonomik, eğitsel, beşeri alanlarda gerçekleştirilen birçok önemli etkinlik sekteye uğramıştır. Bunların yanında insanların günlük yaşam rutinlerinin de bu süreç içerisinde sertçe değiştiğini söylemek mümkündür. Süreçte karşımıza çıkan "yeni normal” kavramı bu yeni düzeni anlatmak ve içselleştirmek için kullanılmakta ve bazı zorunlu davranış değişikliklerini tasvir etmektedir.

Pandemi sürecinin başlangıcıyla birlikte, birçok okul, üniversite ve eğitim kurumu kapılarını süresiz olarak kapatmış, dünya üzerinde tüm yaş gruplarından yaklaşık bir buçuk milyar öğrenci yüz yüze eğitimden uzaktan eğitim faaliyetlerine geçiş yapmıştır (UNESCO, 2020a; UNICEF, 2020b). Acil uzaktan eğitim (AUE) olarak adlandırılan bu eğitsel tepki, pandemi sürecinin getirdiği eğitsel olumsuzluklara hılı bir şekilde cevap vermiştir. Bu çalışmada COVID-19 pandemi sürecinde dünya genelinde yapılmış AUE araştırmaları içeriksel olarak analiz edilmiş, acil uzaktan eğitim sürecinde bazı tanımlayıcı veriler, öne çıkan kavramlar, sorunlar ve çözüm önerileri incelenmiştir.

\section{Acil Uzaktan Eğitim (AUE)}

Eğitim kurumlarının kapatılması, sosyal mesafe kuralları ve değişen kişisel/toplumsal hassasiyetlerle birlikte tüm dünyada, acil uzaktan eğitim olarak kavramlaştırılan süreç, baskın eğitim faaliyeti haline gelmiştir. Alanyazında, acil uzaktan öğretim veya acil uzaktan öğrenme olarak da karşımıza çıkabilen eğitsel süreçler, gerekli iletişim araçları kullanılarak tüm yaş gruplarında hızlı bir şekilde dünya genelinde uygulanmaya başlanmıştır. $\mathrm{Bu}$ süreçteki ana hedef ise, aksayan eğitsel faaliyetlere acil olarak geçici çözümler oluşturabilmektir. Bu geçici çözümler, aslında öğretici ve öğrenenleri çeşitli çevrimiçi teknolojiler yardımıyla hızlı bir şekilde bir araya getirme refleksi olarak tanımlanabilir. Bir başka deyişle bu süreç, planlı uzaktan eğitsel süreçler bağlamında düşünüldüğünde, mükemmel olması beklenmeyen eğitsel deneyimler sunan bir tamir süreci olarak değerlendirilebilir (Hodges ve diğerleri, 2020). Bu noktada üzerinde durulması gereken, "uzaktan eğitim" ve "acil uzaktan eğitim" kavramlarının birbirlerinden oldukça farklı kavramları yansıttığı gerçeğidir. Buna göre;

- Uzaktan eğitim planlı öğrenme-öğretme faaliyetleri içeren, birçok farklı bileşene sahip multidisipliner bir eğitim ekosistemiyken, AUE ise pandemi sürecinin getirdiği "zorunluluktan doğmuş" (Bozkurt vd., 2020) bir öğretimsel iletişim yöntemidir.

- AUE, uzaktan eğitim gibi uzun vadeli sürdürülebilir bir öğrenme ekosistemi kurma amacında değildir. Bunun yerine kriz zamanlarında öğrenenlere geçici bir öğretimsel destek sunulmasını amaçlar.

- Uzaktan eğitim planlı, sistematik ve güçlü kuramsal temellere dayalı ve belirli öğrenme kültürlerine hitap edebilen bir sistemdir. AUE, kriz zamanlarında teknolojik araçların yardımıyla uzaktan erişimle öğrenme faaliyetlerini yüz yüze eğitime benzetme sürecidir.

COVID-19 pandemisiyle beraber tüm dünyada yoğun olarak uygulanmaya başlanan AUE faaliyetleri, bir taraftan önemli kazanımlar vadederken, diğer taraftan ise üzerinde durup düşünülmesi gereken problemleri de beraberinde getirmiştir. AUE sürecinin getirdiği yeni eğitimsel alışkanlıklar ve dahası yaşam stili, pandemi sonrası süreçte gerçekleştirilecek uzaktan veya yüz yüze eğitim faaliyetlerini derinden etkileyebilecek 
deneyimler barındırır. Özellikle AUE sürecinde eğitimcilerin yaşadıkları içerik geliştirme, doğru teknolojileri bulma, öğrenme ve kullanma gibi sorunlar veya bu süreçte kişisel verilerin kullanımına bağlı gelişen etik endişeler uzun vadede uzaktan eğitime karşı bir direnç ve isteksizlik oluşmasına zemin hazırlayabilir. Bu açıdan bakıldığında, COVID-19 pandemi süreciyle birlikte hayatımıza giren AUE kavramı, planlı uzaktan eğitim kavramından ayrılabilmeli ve farklı bir kavramsal yapı içinde eğitim paydaşlarına anlatılabilmelidir.

Birçok ülkede eğitim kurumlarının COVID-19 ile beraber gelen kriz ortamına hazırlıksız yakalandığ1 söylenebilir. Bunun nedeni ise açıkça, bu eğitim kurumlarının daha önce benzer bir felaket senaryosu veya deneyimle karşılaşmamış olmasıdır (Sangster, Stoner, ve Flood, 2020). Eğitim kurumlarıyla beraber birçok uzman, öğretmen, akademisyen veya velinin COVID-19 pandemisinin yarattığı etki karşısında yönetsel, teknolojik ve pedagojik olarak hazırlıksız olduğu, farklı ülkelerin AUE süreci yansımaları ile net olarak gözlemlenebilir. Bu konuda Bozkurt ve diğerleri (2020) ve Sangster, Stoner, ve Flood' un (2020) araştırma raporları önemli yansımalar sunmaktadır.

\section{Problem Durumu}

Özel veya kamusal belirli bir yönetim sisteminde acil durum/kriz yönetim aşamaları genel olarak Şekil 1' deki haliyle ifade edilebilir (Fakhruddin, Blanchard, ve Ragupathy, 2020; Khan, Vasilescu, ve Khan, 2008). Birçok disiplinde kriz yönetiminde kullanılabilen bu aşamalar, COVID-19 pandemisiyle birlikte yıkıma uğrayan ve kriz yaşayan eğitim sistemleri için de geçerli görülebilir. Buna göre COVID-19 pandemisinin oluşturduğu eğitsel kriz ortamı karşısında, ilk aşamada oluşan eğitsel tepki/cevap AUE faaliyetleridir. Bu faaliyetler önceden de belirtildiği gibi öğrenci, öğretmen ve öğrenme içeriklerini teknoloji ile hızlı bir şekilde bir araya getirilme çabası olarak nitelendirilebilir. Bu süreci takiben yeni alışkanlık ve yaşam normlarının yerleşmesi ve eğitsel olarak toparlanma periyodunda, AUE sürecinde karşılaşılan problemlerin tekrar yaşanmaması veya kısıtlanması için süreçte yaşanan sorunların veya iyi örneklerin tespit edilmesi gerekmektedir. Çeşitli akademik veritabanlarında gerçekleştirilen aramalarda pandemi dönemi uzaktan eğitim faaliyetlerini ele alan çok sayıda çalışma bulunmakla birlikte AUE sürecinin dikkat edilmesi gereken kavram, sorun ve çözüm önerilerini bütüncül olarak raporlamak önemli gözükmektedir. Bu bağlamda, pandemi süreci veya sonrası eğitsel faaliyetlerin "yeniden planlanması ve inşaa edilmesi" aşaması ve olası bir sonraki krizde benzer sorunlara mazeretsiz şekilde hazırlıklı olunabilmesi, mevcut kavram ve sorunların doğru şekilde değerlendirilebilmesine bağlıdır.

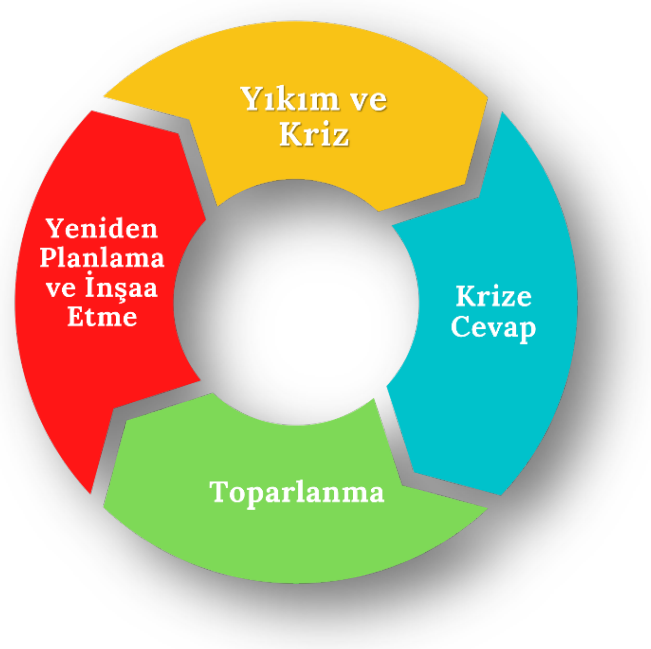

Şekil 1. COVID-19 Eğitim Yönetimi Aşamaları (Khan,

Vasilescu, ve Khan'dan (2008) uyarlanmıştır) 


\section{Araştırmanın Amacı}

$\mathrm{Bu}$ çalışma öncelikli olarak pandemi süreçlerinde gerçekleştirilen AUE faaliyetlerine ilişkin öne çıkan eğitsel kavramlar, yaşanan sorunlar ve eğitsel önerileri küresel düzeyde analiz ederek, ilgili sorun veya önerileri yerel ve küresel bağlamda izlemeyi/değerledirmeyi amaçlamaktadır. Bu doğrultuda araştırmanın temel hedefi elde edilen bulgulardan yararlanılarak, pandemi dönemi veya sonrasında gerçekleştirilecek planlı uzaktan eğitim faaliyetleri için tematik/kategorik önerileri bir araya getirmektir.Araştırma kapsamında aşağıda yer alan araştırma sorularına cevap aranmıştır.

1. AUE sürecinde öne çıkan eğitsel kavramlar nelerdir?

2. AUE sürecinde yaşanan olumsuz durum ve sorunlar nelerdir?

3. AUE süreci ve sonrası için araştırmacıların uzaktan eğitim ile ilgili önerileri nelerdir?

\section{Yöntem}

Bu çalışma, COVID-19 pandemi döneminde gerçekleştirilen acil uzaktan çalışmalarına ilişkin sistematik bir tarama/haritalama çalışmasıdır. Çalışmayla beraber pandemi süreci AUE faaliyetlerinin tematik olarak incelenmesi amaçlanmıştır. Bu sebeple çalışma etik kurul izin belgesi gerektirmemektedir.

\section{Araştırma Deseni}

Sistematik tarama/haritalama çalışmaları öncelikli olarak belirli bir konu alanındaki "son durumu” özetleyen, bunu gerçekleştirmek için çeşitli betimsel/tanımlayıcı bilgileri kullanan spesifik bir metodolojidir (Clapton, Rutter, ve Shariff, 2009). Sistematik taramalar, konu alanındaki mevcut çalışmaları seçip katkılarını değerlendirme amacıyla ilgili çalışmaların analiz, sentez ve raporlamasını yapar. Sistematik haritalama çalışmaları genellikle bir konu alanının erken bilimsel gelişiminde kullanılır ve kanıta dayalı uygulamaların gerçekleştirilebilmesinde ilk basamak olarak kullanılabilir (Grant ve Booth 2009; Peters ve Wood, 2017; Petticrew ve Roberts, 2008). Bu araştırmada da pandemi dönemi mevcut AUE araştırmalarının durumu, yönelimler ve çeşitli dönemsel unsurlar incelenerek, pandemi ve sonrası planlı uzaktan eğitim faaliyetleri için araştırmacılara yol haritası oluşturulmaya çalışılmıştır.

\section{Dahil Edilen Çalışmalar}

Araştırma kapsamında bilimsel makaleler, tam metin bildiriler ve bilimsel kitap bölümlernden faydalanılmış verilerin yorumlanması aşamasında gri literatürden de (genellikle bir hakem değerlendirmesinden geçmeyen ya da bilimsel yayın kriterlerini tam olarak sağlamayan magazin dergisi makaleleri, görüş yazıları, gazete haberleri vb.) faydalanılmıştır. Araştırmada analiz edilen çalışmalar; SCOPUS, Web of Science, Science Direct, Emerald Insight, IEEEXplore, ACM Digital Library, EBSCO host araştırma veritabanları (Academic Search Premier, H.W. Wilson, British Education Index, ERIC vd.), JSTOR ve Google Akademik veri tabanları aracılı̆̆ıyla toplanmıştır (Tablo 1). Araştırmada, ilgili veritabanlarında gerçekleştirilen sorgular; "emergency remote AND (education OR teaching OR instruction OR learning) sorgusu ve Boolean operatörleri aracıllğıyla gerçekleştirilmiştir. Sorgular başlık, anahtar kelime ve özetler düzeyinde gerçekleştirilmiştir. Buna ek olarak yalnızca 2019 ve 2020 tarihli araştırmalar incelenmiş ve dilsel bir kısıtlamaya gidilmemiştir. Bulunan çalışmalar arasında erişim sağlanabilen çalışmalar araştırmaya dahil edilmiştir. Bununla beraber kulanılan sorgu kelimelerini içerse de eğitim, öğrenme, öğretim ile ilgili olmayan belirli bir konuya odaklanmış çalışmalar (üretim, ekonomi, sağlık stratejisi vb.) araştırma dışında bırakılmıştır. Ayrıca sorguda belirtilse de sorgu sonuçlarında listelenen alan notları (field notes) ve özel sayı çağrıları gibi metinler çalışma kapsamından çıkarılmıştır. Araştırmada etik ihlal yaratabilecek herhangi bir veri kullanılmamıştır. 
Tablo 1

Analize Dahil Edilen Çalışmalar ve Yararlanılan Veritabanları

\begin{tabular}{ll}
\hline Veritabanı & $\mathbf{n}$ \\
\hline Web of Science & 161 \\
Science Direct & 14 \\
SCOPUS & 316 \\
Emerald Insight & 512 \\
IEEEXplore & 166 \\
ACM Digital Library & 166 \\
EBSCO host research databases & 460 \\
JSTOR & 369 \\
Google Akademik & 371 \\
Toplam & 2535 \\
\hline
\end{tabular}

Son durumda araştırmada 152 çalışma dahil edilmiştir. Dahil edilen çalışmaların 16'sı "acil uzaktan eğitim", 45’i “acil uzaktan öğrenme”, 19’u "acil uzaktan öğretim (instruction)" ve 72' si ise "acil uzaktan öğretim (teaching)" arama terimleriyle bulunmuştır. Aynı çalışmada birden fazla arama sorgusu verisi yer alabilse de, pandemi döneminde genellikle "acil uzaktan öğretim (teaching) kavramının kullanıldığı göze çarpmaktadır.

\section{Veri Analizi}

Verilerin analizinde tematik içerik analizi ve mümkün olduğu durumlarda da betimleyici analiz verileri (hedef konu alanları, ülkelere göre yayın yoğunluğu) kullanılmıştır. Araştırma kapsamında genel analiz ve raporlama süreci Şekil 2'de sunulmaktadır.

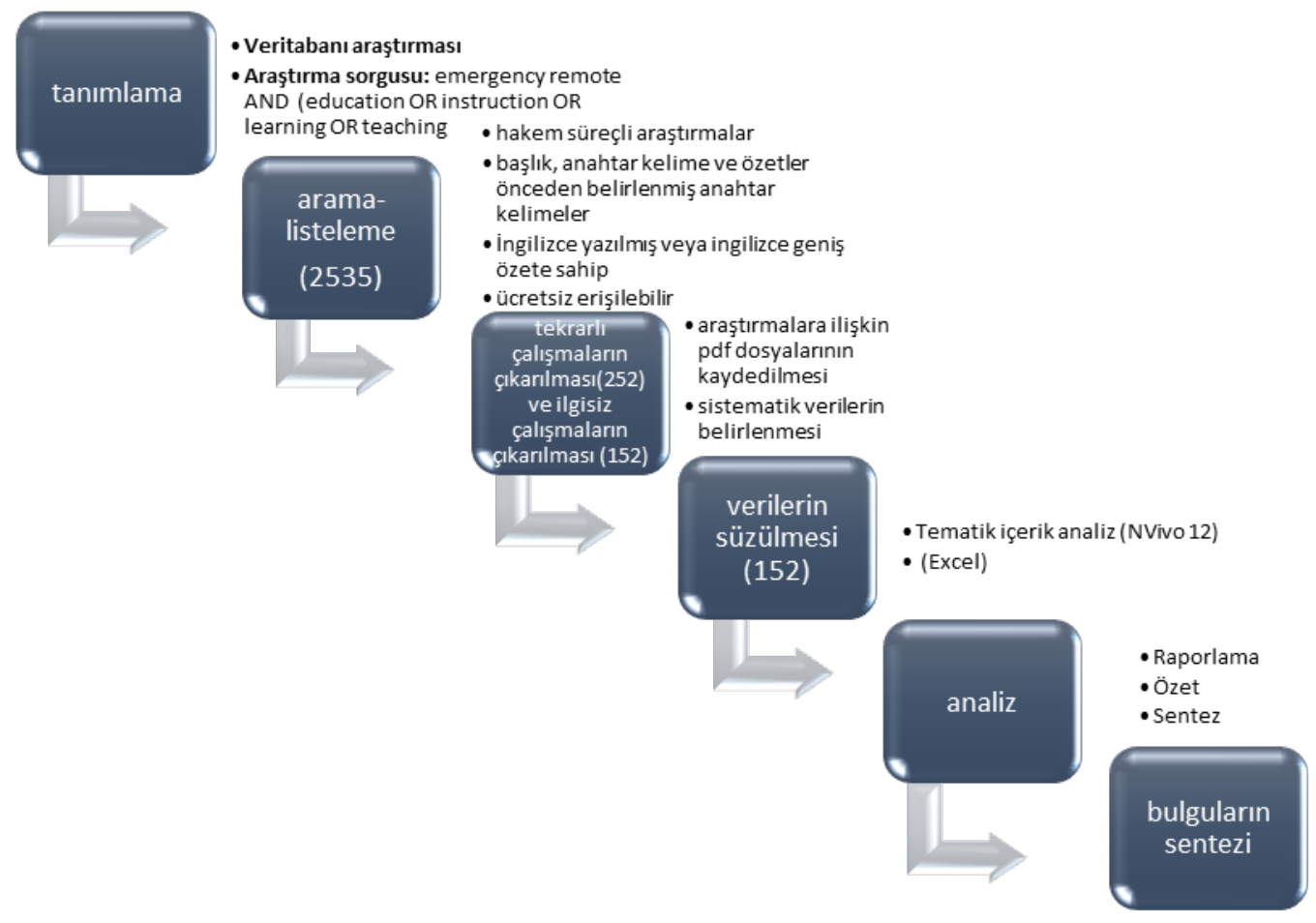

Şekil 2. Araştırma Süreci 
Araştırmanın veri seçim sürecinde il olarak toplam 2535 çalışma listelenmiş, birbirini tekrar eden çalışmalar çıkarıldığında ise toplam 252 çalışma ilk analize dahil edilmiş, konu alanı ile ilgili olmayan çalışmalar dışarıda bırakıldığında ise son durumda 152 çalışma detaylı olarak analiz edilmiştir. Tematik analiz, bir veri setindeki olası temaları analiz etme, tanımlama ve raporlamaya yarayan, bağımsız nitel bir analiz yöntemidir (Braun ve Clarke, 2006, s.79). Bu yöntemde metinler üzerinde kodlama yapılarak kod kategorileri oluşturulur (Hsieh ve Shannon, 2005). Analiz aşamasında Nvivo 12 nitel analiz programından faydalanılmış, açık kodlama adımları takip edilmiştir. Öncelikli olarak veriler kavramsallaştırılmış, sistematik olarak sınıflandırılmıştır. Daha sonra ise ilgili sınıflandırmalara göre araştırma temaları belirlenmiştir (Strauss ve Corbin, 2008).

\section{Geçerlik ve Güvenirlik / İnandırıcılık Sağlama Amacıyla Alınan Önlemler}

$\mathrm{Bu}$ araştırmanın analiz sürecinde yazar ve diğer bir alan uzmanı tarafından kodlayıcılar arası (inter-rater) ve kodlayıcı içi (intra-rater) analiz tekrarı yöntemi kullanılarak araştırmanın güvenirliğine katkıda bulunulmaya çalışılmıştır. Tematik kodlama gerçekleştirilen çalışmalarda, kod grubu ve temaların doğru oluşturulması oldukça önemlidir. Bu bağlamda araştırmacı ilk analizi gerçekleştirdikten 20 gün sonra analizi tekrarlamış ve ilk analiz kod grubu ve kategorilerine göre kodlayıcı içi güvenirlik katsayısı belirlenmiştir. Bununla beraber araştırmaya dahil edilen çalışmaların \% 10’u bir başka alan uzmanı tarafından önceden belirlenen kategorilere göre kodlanmış ve kodlayıcılar arası güvenirlik katsayısı hesaplanmıştır. Kodlayıcılar arası ve içi güvenirlik katsayıları hesaplanırken Cohen Kappa katsayısı kullanılmıştır. Araştırmanın analiz sürecinde elde edilen kodlayıcılar arası ve kodlayıcı içi güvenirlik katsayıları sırasıyla $\kappa=0.828$ ve $\kappa=0.982$ olarak hesaplanmıştır. $\mathrm{Bu}$ değerler analiz birimleri arasında gerçekleştirilen eş kodlamalar arasında mükemmel uyum olduğunu işaret etmektedir (Landis ve Koch, 1977).

\section{Sinırlılıklar}

$\mathrm{Bu}$ araştırmanın bazı sınırlıklıkları bulunmaktadır. Bunlardan ilki ve en önemlisi çalışmanın yalnızca kısmi bir veri seti üzerinde gerçekleştirilmiş olmasıdır. Araştırma kapsamında yalnızca giriş ve yöntem kısımlarında belirtilen veri tabanları kullanılmıştır. Bununla birlikte araştırmaya yalnızca AUE süreçlerini konu edinen çalışmalar dahil edilmiştir. Bunun nedeni ise COVID-19 pandemi dönemi eğitim süreçlerini içeren yaklaşık 20.000 çalışmaya ulaşılmış olmasıdır. Bu sayı, tematik olarak bu dönemde yapılan çalışmaların analizinin yapılmasını oldukça güçleştirmektedir. Bu bağlamda COVID-19 süreci uzaktan eğitim faaliyetlerini AUE olarak doğru tanımlayan çalışmalardan kısmi bir harita ortaya konulması uygun görülmüştür. Bununla birlikte araştırma, akademik dergilerde yayınlanan bilimsel makale, bildiri, kitap bölümleri ile sınırlıdır. Yorumlama aşamasında gri literatürden yararlanılsa da, bu çalışmalar analize dahil edilmemiştir. Buna ek olarak Google Akademik sorgusu yalnızca başlık düzeyinde gerçekleştirilmiştir. Bu tür araştırmalarda bulunan bir diğer sınırlılık ise tematik içerik analizin nitel araştırmanın doğası ile ilgili ilerleme sürecidir. Kodlayıcı güvenirliği hesaplandığında elde edilen katsayılar, tamamiyle kodların objektif şekilde oluşturulduğu anlamına gelmeyebilir (Loffe ve Yardley, 2004). Bu açıdan bakıldığında bulguların kalitesi, araştırmanın sunduğu ve çalışılan konuya katkı getirebilecek yeni ve farklı öngörüleri ile değerlendirilebilir (Krippendorff, 2004).

\section{Bulgular ve Sonuç}

Araştırmada gerçekleştirilen betimsel ve tematik analiz sonrasında, araştırma sorularından da yola çıarak, pandemi dönemi uzaktan öğrenme deneyimleri, “öne çıkan kavramlar", "sorunlar”, ve “öneriler” ana kategorilerinde incelenmiştir. Bunlarla beraber bazı basit tanımlayıcı veriler de sunulmuştur (hedef kitle, öne çıkan ülkeler). Elde edilen bulgulardan, “öne çıkan eğitsel kavramlar” beş kategori (Tablo 2), sorun ve olumsuzluklar ise 11 anatema altında (Şekil 5) betimlenmiştir. Öneriler ise sonuç bölümünde diğer araştırma bulgularıyla da sentezlenerek altı kategoride sunulmuştur. 


\section{Çalışmaların Hedef Kitleleri}

Araştırma kapsamında, pandemi dönemi "acil uzaktan öğretim” sürecinde gerçekleştirilen çalışmaların çoğunlukla yükseköğretim düzeyinde gerçekleştirildiği (\% 66,29) gözlenmiştir. Spesifik hedef gruplarından öğretmen eğiticilerin (\% 11,24) de yükseköğretim bağlamında değerlendirilmesi ile, K-12 düzeyi (\% 12,36) ve bu düzeyde görev alan hizmetiçi öğretmenlerin $(\% 8,99)$ eğitim deneyimlerini konu edinen çalışmaların azınlık olarak kaldığı görülmüştür. COVID-19 pandemi sürecinde uzaktan eğitime geçen yaklaşık bir buçuk milyar öğrenenin büyük çoğunluğunun yükseköğretim düzeyi altında öğrenim gören öğrenenler olduğu düşünüldüğünde (Dünya Bankası, 2017) bu bulgu "beklenmedik" bir bulgu olarak değerlendirilebilir.Elde edilen bulgudaki bu duruma acil uzaktan öğretim faaliyetlerine ilişkin başta yükseköğretimde başlayan dijital dönüşüm ve eğitim politikası değişikliklerine ilişkin yol haritalarının belirsizliği neden olmuş olabilir. Ayrıca yükseköğretim düzeyinde araştırma yapan akademisyenlerin pandemi sürecinde K-12 düzeyinde araştırma yürütme faaliyetlerinin sekteye uğramış olduğu da akılda tutulmalıdır.

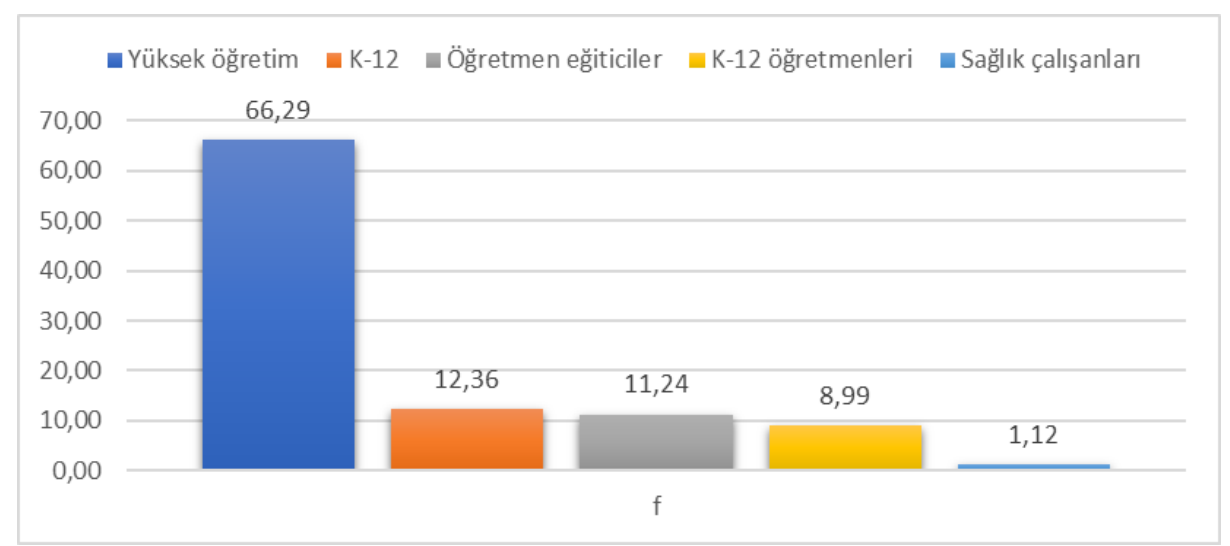

Şekil 3. Araştırma Kapsamında Ele Alınan Çalışmaların Hedef Konu Alanları

\section{AUE Döneminde Ülkelere Göre Yayın Yoğunluğu}

Pandemi dönemi acil uzaktan öğretim çalışmaları yayının yapıldığı ülke bağlamında incelendiğinde çalışmaların A.B.D, Kanada, Filipinler, İngiltere ve Almanyanın başı çektiği ülkelerde yoğunlaştığı görülmüştür (Şekil 4).

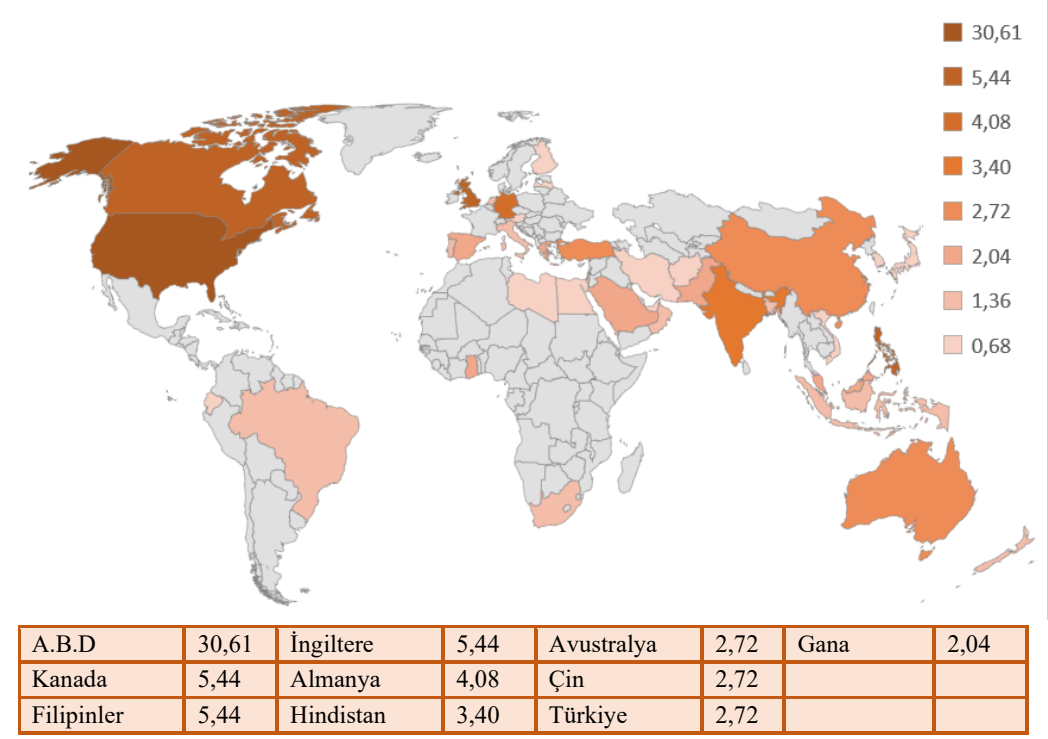

Şekil 4. Acil Uzaktan Öğretim Döneminde Ülkelere Göre Yayın Yoğunluğu Yüzdeleri 
Genellikle gelişmiş veya gelişmekte olan ülkeler (kişi başına düşen milli gelire göre) veya insani gelişme indeksine göre (Human Development Report, 2020) değerlendirildiğinde, önde gelen ülkelerin acil uzaktan öğretim sürecine ilişkin farklı perpektifleri ortaya koyarak disipliner şekilde ulusal eğitim süreçlerinin sürdürülebilir yapılarını korumak istedikleri yorumu yapılabilir.

\section{AUE Sürecinde Öne Çıkan Kavramlar}

\section{Tablo 2}

AUE Döneminde Öne Çıkan Eğitsel Kavramlar

Öğrenme Öğretme Süreç ve Yaklaşımları

Esnek öğrenme, hibrit öğrenme, Hyflex (hybrid flexible) öğrenme

Modüler esneklik

Dönüştürülmüş sınıflar \& Çevrimiçi dönüştürülmüşs snıf modeli

Bilginin işbirlikli inşası \& paradoksal öğrenme \& Dragon Dreaming yöntemi

Topluluk oluşturma \& Aidiyet hissi \& Sorgu toplulukları oluşturma

Teknolojik pedagojik alan bilgisi kavramsal çerçevesi

Yaparak öğrenme \& Çevrimiçi sanal laboratuvarlar \& Ev deney kitleri

Sanal bilim fuarı

"Önce öğrenenler" yaklaşımı

Süreç değerlendirme \& Geçti-Kaldı notlandırması \& Esnek not

Alternatif ölçme ve değerlendirme yöntemleri

Evde okul \& Ev merkezli oyun etkinlikleri

Empati \& nöro-eğitim

Erişilebilirlik/Öğrenmede evrensel tasarım \& uyarlanabilir tasarım \& kapsayıcı pedagoji

Travma farkındalıklı eğitsel uygulamalar

\section{Süreç Tasarımı}

Devamlı destek \& Geribildirim (Video geribildirim, hemen geribildirim, anonim geribildirim)

Tasarım için dar zaman

Öğretim videosu hazırlama

Podcast kullanımı

Bilişsel yük

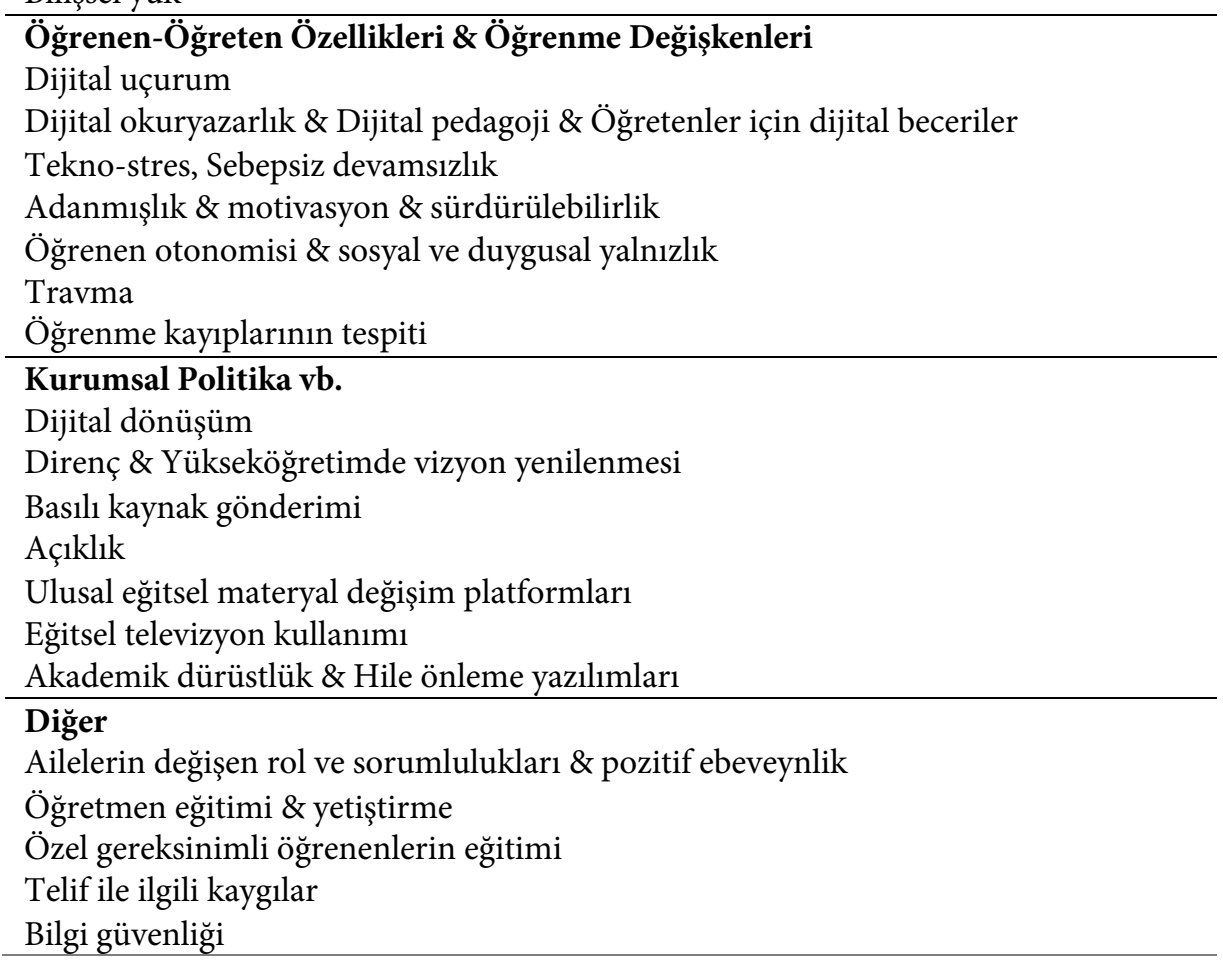


AUE süreci deneyimlerini yansıtan araştırmalarda vurgu yapılan/ön plana çıkan kavramları belirleyebilmek için, ilgili araştırmaların anahtar kelimeleri incelenmiş ancak yalnızca yazar anahtar kelimeleri ile sinırlı kalınmamıştır. Araştırmaya dahil edilen çalışmaların tamamı yazar tarafından otuz gün arayla hızlıca gözden geçirilmiş, kullanılan anahtar kelimelere ek olarak çalışmalarda vurgulanan anahtar kavramlar belirlenmiştir. Bu noktada yazar öne çıkan kavram analizi için kodlayıcı içi güvenirliğinden yararlanmış, Cohen kodlayıcı güvenirliği katsayısı 0.985 olarak hesaplanmıştır. Tablo 2' de AUE döneminde öne çıkan eğitsel kavramlar listelenmiştir.

Öne çıkan kavramlar incelendiğinde AUE faaliyetleriyle başlayan süreçte özellikle esnek öğrenme, hibrit öğrenme ve hibrit esnek (Hyflex) öğrenme kavramlarının kullanımlarının arttığı göze çarpmaktadır. Bunlardan esnek öğrenme daha genel bir çevrimiçi öğrenme yapısını ifade eder. Öğrenenler esnek öğrenme ortamlarında zaman, mekan, öğrenme hızı gibi değişkenler bağlamında özgür olmakla birlikte, buna ek olarak ölçme, ders planı, içerik gibi konularda da esneklik söz konusudur (Houlden ve Veletsianos, 2020; Naidu, 2017). Hibrit öğrenme ise kampüs içi yüz yüze ve kampüs dışı çevrimiçi öğrenme faaliyetlerinin dönem içinde planlı bir yöntemle, aşamalı olarak bir arada kullanılmasını ifade etmektedir. Hibrit esnek (Hyflex) öğrenme ortamları, öğrenenlerin yüz yüze veya çevrimiçi olarak bir öğrenme sürecine /derse nasıl ne zaman ve nasıl katılacaklarını kendilerinin seçebildiği bir yöntem olarak ortaya çıkmıştır.

AUE süreciyle birlikte çevrimiçi öğrenme süreçlerinin nasıl daha etkili ve verimli kullanılabileceği ile ilgili yaklaşımların ön plana çıkması oldukça doğaldır. Öğrenen ve öğretenler arasındaki etkileşimsel ve duygusal uzaklığın yer aldığı çevrimiçi öğrenme süreçlerinde, beklenen öğrenme ediniminde azalma yaşanabilir. Bu bağlamda dönüştürülmüş ve çevrimiçi dönüştürülmüş öğrenme yaklaşımı, çevrimiçi topluluk ve bu toplulukların sorgu temelli işe koşulması, öğrenen grupları arasında aidiyet hissi yaratılması, bilginin işbirlikçi olarak oluşturulmasına ve proje/tasarıma dayalı yaklaşımlar (paradoksal öğrenme, day dreaming yöntemi vb.), çevrimiçi ortamlarda alternatif "yaparak deneyerek öğrenme” yaklaşımları ve oyun temelli öğrenme-öğreme yaklaşımlarının kullanımı daha verimli çevrimiçi deneyimler için kritik öneme sahip olabilir. Burada dikkat edilmesi gereken nokta ise tüm bu süreç ve yaklaşımların AUE dönemi travma farkındalıklı olarak planlanabilmesi gerekliliğidir. İlgili dönemde "empati”, kurumlar, öğretenler ve öğrenenler için akılda bulundurulması gereken bir kavram olarak belirmektedir. Öğrenme-öğretme yaklaşımları kategorisindeki öne çıkan kavramlar genel olarak incelendiğinde öğrenen merkezli, öğrenenler için yüksek oranda esnek, ve geçiş döneminde kesin kısıtlara dayanmayan yaklaşımlara ilişkin kavramların daha çok vurgulandı̆̆ı gözlenmiştir. Öne çıkan diğer kavramlar incelendiğinde kavramların; öğrenme süreci tasarımı, öğrenen-öğreten özellikleri, öğrenme değişkenleri ve kurumsal politikalarla ilgili kategorilerinde gruplandırılabildiği görülmektedir.

Bu süreçte özellikle çevrimiçi içerik tasarımıyla ilgili unsurların nasıl doğru şekilde kullanılması gerektiği ve bu içeriklerin öğrenenlere farklı yöntemlerle nasıl ulaştırılabileceği konusuna da vurgu yapılmıştır. Modüler çevrimiçi ders tasarımı, ders videolarının uzunluğu, ders eğitmeninin görsel bulunuşluğu, çevrimiçi toplantı ve videolarda ses unsurları, ders tasarımları gerçekleştirilirken geribildirimin önemi, düşük internet hız ve kotaları için uygun formatların kullanımı (podcast vb.) konuları ön plana çıkmıştır. Ders tasarımlarından kaynaklanabilecek bilişsel yük kavramı da dikkat çekici bir konu olarak göze çarpmaktadır. İlgili tasarım süreçleri için ise öğretici ve uzmanların daha geniş zaman ihtiyaçlarına sürekli vurgu yapılmıştır. Bu durum ise aslında uzaktan eğitimde süreç ve öğrenme tasarımı etkinliklerinin uzman ekiplerce işbirlikli olarak gerçekleştirilmesi gerektiği konusunda önemli bir ipucudur.

Öğrenen-öğreten özellikleri ve öğrenme değişkenleri kategorisinde öne çıan konulardan dijital uçurum, genel olarak, çeşitli kısıtlardan dolayı (ekonomik, coğrafi vb.) bireyin teknolojiye ulaşamaması durumunu anlatır. Bunun yanında çevrimiçi içerik üretme veya bu içeriklere ulaşabilme becerisi, çevrimiçi ortamlarda pedagojik yaklaşım, dijital okuyazarlık ve bazı dijital becerilerin, bunların yanında (öğrenme sürecinin içine girildikten sonra) uzaktan öğrenme sürecine adanmışlık, motivasyon,ve sürdürülebilirlik, gibi konuların doğal olarak 
AUE sürecinde öne çıkan kavramlardan olduğu görülebilir. Stres, tekno-stres, travma, depresyon gibi kavramlarının da AUE araştırmalarında en yoğun karşılaşılan kavramlardan olduğu belirlenmiştir.

Kurumsal politika kategorisinde öne çıkan konular genellikle dijital dönüşüm ve açıklık kavramları çerçevesinde çeşitlenmiştir. AUE döneminde ulusal eğitim politikalarının ve yükseköğretim kurumlarının uygulamaları, AUE sürecinde yaşanan öğrenme deneyimlerinde önemli belirleyiciler olarak karşımıza çıkmaktadır. AUE sürecinde, ebeveynlerin, çocuklarının eğitimi süreçlerinde değișen rol ve sorumlulukları, değişen rol ve sorumlulukları karşısında ebeveynlerin tutumları, bunlarla beraber tekno-pedagojik yeterlilikli öğretmen eğitimi, araştırmalarda öne çıkan staratejik konulardandır. Özel gereksinimli öğrenenlerin eğitiminde yaklaşım ve sorunlar, eğitim süreçlerinde kullanılan yazılımlar nedeniyle yaşanan telif ile ilgili kaygılar ve bilgi güvenliği, yine araştırmalarda önemle vurgulanan konular arasındadır.

\section{AUE Sürecinde Yaşanan Sorun ve Sınırlılıklar}

AUE sürecinde yaşanan sorun ve sınırlılıklar 11 anatema altında 79 maddede ortaya konulmuştur.

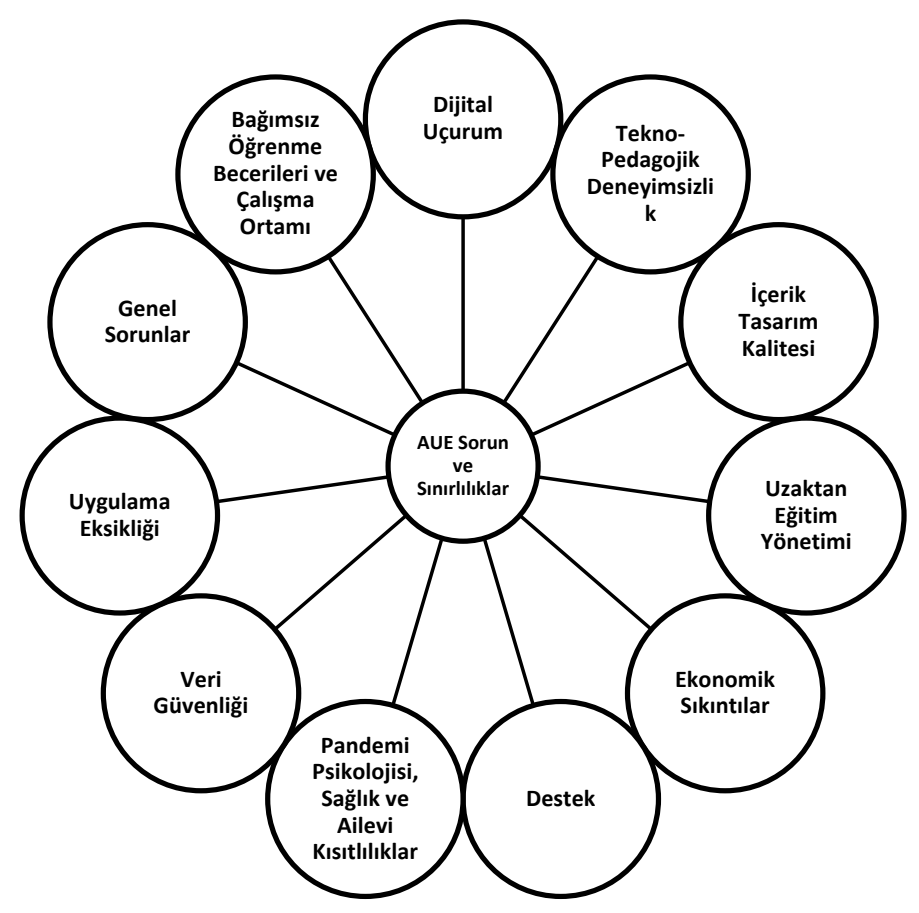

Şekil 5. AUE Sürecinde Yaşanan Sorun ve Sınırlılıklar Anatemaları

\section{Dijital uçurum}

Bir önceki bölümde de belirtildiği üzere, dijital uçurum bilgisayar, internet gibi dijital teknoloji unsurlarına sahip olmamaktan kaynaklı (Warschauer, 2004) önemli bir bilgiye erişim kısıtıdır. Bu araştırmada elde edilen bulgular dijital uçurum tanımını genişletmek için kullanılabilir. AUE sürecinde internet bağlantısının kısıtlı (kotalı) olması, internet bant genişliğinin düşüklüğü neticesinde bazı çevrimiçi içerikleri yerinde ve zamanında görüntüleyememe, ekonomik imkansızlıklar (lisans/kullanım hakkı bağlamında) ya da bilgisayar donanım özelliklerinden dolayı bazı çevrimiçi araç veya materyalleri kullanamama, sık yaşanan elektrik kesintileri veya yine teknolojik cihaz noksanlığına bağlı olarak teknolojik araçların ailenin diğer bireyleriyle paylaşılması zorunluluğu, AUE döneminde öğrenme deneyimlerini derinden etkileyen dijital uçurum durumuna neden olmuştur. 
Tablo 3

Dijital uçurum anateması
Kısıtllı internet bağlantısı
İnternet bant genişliğinin kırsal kesimlerde genel olarak azalması
Teknolojik cihaz noksanlığı
Donanım ve yazılım yetersizlikleri
Bazı çevrimiçi araç veya materyallerin kullanım hakları/lisans eksikliği
Kırsal kesimlerde sık yaşanan elektrik kesintileri
Teknolojik araçların ailenin diğer bireyleriyle paylaşılması zorunluluğu

\section{Çevrimiçi öğrenmeye ilişkin tekno-pedagojik deneyimsizlik ve olumsuzluklar}

$\mathrm{Bu}$ anatema altında yer alan "yaşanan sorun ve sınırlılıklar", öğrenen ve öğretenlerin çevrimiçi öğrenmeöğretme süreçlerine alışkanlık ve hazırbulunuşluklarıyla beraber değerlendirilebilir. Ancak ilgili sorun ve sinırlılıklar, temelde AUE sürecinde yaşanan zaman kısıtları ile, öğretmenler veya uzmanlar (eğitim uzmanları, akademisyen vb.) arasındaki uzaktan eğitim ile ilgili pedagojik bilginin ve etkileşim tasarımı bilgisinin zayıflığına da işaret etmektedir. Bulgular incelendiğinde öğrenen tarafında dijital okuryazarlık ve teknolojik okuryazarlık eksiklikleri rapor edilmemesi dikkat çekicidir.

Tablo 4

Çevrimiçi Öğrenmeye İlişkin Tekno-Pedagojik Deneyimsizlik ve Olumsuzluklar Anateması

Uzaktan eğitim deneyimi olmayan öğreticilerin teknolojik okuryazarlık ve pedagojik bilgi yetersizliği Öğrenme motivasyonu ve adanmışlı̆̆ sağlama konusunda pedagojik yaklaşım eksiklikleri

Çok fazla ödev verilmesi sonucu motivasyon kaybı

Üretken öğrenme ortamları oluşturma ve öğrencilerle etkileşim kurabilme yetersizlikleri

Öğrenenleri farklı farklı öğrenme format, yaklaşım veya araçlarıyla destekleme eksikliği

Öğrenenleri geleneksel yöntemlerle değerlendirme eğilimi

Dijital içerik üretmenin zorluğu, bunun yanında çevrimiçi içerik hazırlama ve harmanlanmış eğitim süreçleri konusunda deneyimsizlik

Kısa sürede bir öğrenme yönetim sisteminde modüler tasarım yapabilmenin zorluğu

Göz teması, vücut ifadesi, sınıf iklimi gibi eksiklikler neticesinde öğrenme-öğretme sürecine odaklanma problemi yaşama

Öğreticilerin kişiselleştirilmiş öğretimi tamamen devre dışı bırakmaları

Planlı ders dönemine uyulamaması

Öğrenen geribildirimi eksikliği

\section{Içerik tasarım kalitesi}

AUE sürecinde tüm öğrenme içeriği tasarımının hem kaliteli hem de hızla oluşturulması konusunda eğitim kurumlarında yüksek beklenti oluşturulmuştur. Uzaktan eğitim kurumları için yaşanan en büyük sorun kaliteli ve kapsamlı bir çevrimiçi içerik oluşturma konusunda yaşanmaktadır. Ders içeriğinin bire bir olarak çevrimiçi ortama aktarılması ile oluşturulan ansiklopedik içerik yapısı, donanıma da bağlı olabilecek video görüntü ve ses kalitesi, öğrenen dikkat süresine önem verilmeden hazırlanan video içerik süreleri AUE sürecinde yaşanan olumsuzluklardandır. 
Tablo 5

İçerik Tasarım Kalitesi Anateması

Ansiklopedik içerik tasarımı

Eşzamansız videoların kalitesi

Ses kalitesi sorunları

Uzun ders videoları hazırlama

Etkili çevrimiçi öğretim tasarım örneklerinin eksikliği

\section{Uzaktan eğitim yönetimi}

AUE süreci öğrenenler, öğretenler ve aileler üzerinde derin etkiler bıraktığı gibi, eğitim kurumları üzerinde de zorunlu bir değişim - dönüşüm süreci başlatmıştır. Uzaktan eğitim süreçleriyle ile ilgili hızlı bir yol haritası oluşturma çabası, çevrimiçi teknoloji entegrasyonu, herkes için eğitim yaklaşımı çerçevesinde eğitim politika veya yönergelerin yeniden ele alınması zorunluluğu gibi konular, AUE sürecinde uzaktan eğitim yönetiminde yaşanan sorunların temellerini oluşturmaktadır.

Tablo 6

Uzaktan Eğitim Yönetimi Anateması

Kurumsal olarak yeni teknolojilere alışmanın zorluğu / direnç
Teknoloji ve öğretim süreçleriyle ilgili politika eksiklikleri, yönetsel yetersizlikler
Uzaktan eğitim araçları/sistemlerinin işe koşulmasında aşamasında zaman darlığı nedeniyle test süreci
gerçekleştirilememesi
Azalan bütçe ve buna bağlı olarak yeni uzman personel ve aktif öğrenen alımının zorlaşması
Öğrenen ve öğreticiler için, kayıtlı içerik ve videolar yerine eş zamanlı derslerin zorunlu tutulması
Ölçme ve sınavlarla ilgili açık ve net bir vizyon olmaması
Mezuniyet, konser, kutlama gibi sosyal öğrenme ortamlarının eksikliği ve sanal etkinlik oluşturma
konusunda kurum ve öğreticilerin eksiklikleri
Akademik dürüstlüğü sağlama konusunda yetersizlik ve güçlükler
Özel gereksinime ihtiyaç duyan öğrenenler için fırsat eşitliği sağlama
Özel gereksinime ihtiyaç duyan öğrenenlerin bakım ihtiyaçlarının artması

\section{Ekonomik sıkıntılar}

COVID-19 pandemi sürecinin yıkıcı etkileri kendini ekonomik alanda oldukça fazla hissettirmiştir. İş kaybı, hastalık süreci, evde bakım zorunlulukları, öğrenen ve eğitmen dolaşımın azalması (uluslararası değişim programları vb.), arzın ve talebin azalması gibi sorunlar AUE süreçlerinde de kendini göstermiştir. Bunların yanında bazı az gelişmiş veya gelişmekte ülkelerde yaşanabilen internet hizmetlerinin pahalılığı durumu bu dönemde ekonomik kısıtlılıklara sebep olabilmektedir. Aşağıda, incelenen araştırmalarda raporlanan bazı ekonomik zorluklar listelenmiştir.

Tablo 7

Ekonomik Sikıntılar Anateması

İş kayıpları

Bazı aile ve öğrencilerde yaşanan gelir/iş kaybı sonrası üniversite harç ödemelerinde zorlanılması

Azalan özel destek-devlet desteği sonucu bütçe zorlukları

İnternetin pahalılığı 


\section{Bağımsız öğrenme becerileri ve çalışma ortamı}

Çevrimiçi öğrenme, yüksek oranda bireylerin öz-düzenlemeli çalışma becerileri ve öğrenme motivasyonlarına bağlıdır. Bu doğrultuda öz-düzenleme becerisi eksikliği ve buna bağlı öğrenme/planlama eksiklikleri AUE sürecindeki öğretim tasarımı sorunlarıyla birlikte daha da belirgin hale gelmiş olabilir. Buna ek olarak AUE sürecinde zamandan bağımsız olma durumu birçok eğitim kurumu tarafından uygulanmamıştır. Araştırma bulguları, bu durumun genellikle evde oluşturulan öğrenme ortamlarında sorunlara neden olduğunu işaret etmektedir.

Tablo 8

Bağımsız Öğrenme Becerileri ve Çalışma Ortamı Anateması

Kişisel öğrenme planlaması eksikliği

Bağımsız öğrenme becerileri eksikliği

Disiplin eksikliği

Dikkat eksikliği

Zaman yönetimi

Evde yeterli çalışma alanı bulamama (fiziksel ortam kısıtları veya kalabalık kaynaklı)

Dağınık ev ortamı

Tam sessizliğin sağlanamadığı pandemi dönemi ev hali

\section{Destek}

Uzaktan eğitim süreçlerinde destek ve geribildirim, öğrenme ortamında genellikle kendi ile baş başa olan öğrenen için önemli bir öğretim-öğrenme tasarımı bileşenidir. AUE sürecinde bu konuda yaşanan sorun veya kısıtlılıklar aşağıda listelenmiştir.

Tablo 9

Destek Anatemas1

Duygusal/ruhsal destek yetersizliği
Eğitim kurumu organizasyonundan kaynaklanan, öğretici ve öğrenenler arasında yaşanan iletişim
eksiklikleri
İletişim araçlarının kullanımı konusunda teknik destek eksikliği
Rehberlik ve destek servislerine erişememe
Aile duygusal desteğinin eksikliği
Eğitmenlere ulaşamama
Yönlendirici çevrimiçi içeriklerin azlığı/eksikliği
Aile ve çocuklar arasında dijital uçurum
Akran geribildirimi yetersizliği

\section{Pandemi psikolojisi, sağlık ve ailevi kısıtıııklar}

Pandemi süreci, bireylerin günlük yaşantısında köklü değişikliklere neden olmuş, bireyler birçok konuda pandemi öncesi alışkanlık, yaşam rutini ve konfor alanlarından çıkmak zorunda kalmışlardır. İncelenen çalı̧maların büyük çoğunluğunda hem öğrenen hem de eğitimciler tarafında stres, depresyon ve çeşitli kaygı bozuklukları rapor edilmiştir. Pandemi psikolojisi, aile yapıları ve değişen yaşam/sağlık koşulları AUE sürecinde de önemli etkiler oluşturmuştur. Bu dönemde, bireylerin eğitsel deneyimlerini etkileyen bazı konular aşağıda listelenmektedir. 
Tablo 10

Pandemi Psikolojisi, Sağlık ve Ailevi Kısıtlllıklar Anateması

Pandemi sürecinde yaşanan stres, endişe, kaygı bozukluğu

Aileden birinin kaybı, kayıp korkusu

Duygusal yorgunluk

Yalnız yaşama

Bazı farklılıkların (etnik, cinsel, dini..vb) pandemi döneminde giderek zor yaşam koşulları oluşturması ve bununla mücadele

Teknoloji korkusu

Öğrenenlerin başka sorumluluklarının baş göstermesi; para kazanma mecburiyeti, aileye destek olma, hasta bakma...vb

Çocuğu olan öğretici veya öğrenenlerin sorumluluklarının çok artması ve zaman yönetiminin güçleşmesi

\section{Veri güvenliği}

Uzaktan eğitim süreçleri genel olarak kitlesel iletişimi destekleyebilen teknoloji bağlamlı süreçlerdir. Dijital iletişim araçlarının kullanıldığı herhangi öğrenme-öğretme sürecinde ise bireylerin kişisel veya sistem kullanımlarına ait verilerinin yüzde yüz oranda gizli tutulabilmesi oldukça zor gözükmektedir. Bunun nedeni uzaktan eğitimde gerçekleştirilen hızlı teknoloji entegrasyonudur. Üzerinde düşünülmeden veya test edilmeden öğrenme süreçlerine entegre edilen araçlar veri güvenliği bağlamında risk oluşturabilir. $\mathrm{Bu}$ bağlamda; örneğin bazı Avrupa ülkeleri, Avrupa Birliği dışındaki bir ülkenin geliştirdiği çevrimiçi araçların kullanımını yasaklamaktadır. Bu durumun asıl nedeni ise veri güvenliği konusunda yaşanan hassasiyetlerdir.

Tablo 11

Veri Güvenliği Anateması

Veri güvenliği nedeniyle bölgesel yazılım veya çevrimiçi araç kısıtlamaları

Veri güvenliğini korumanın özellikle pandemi döneminde güçleşmesi

\section{Uygulama eksikliği}

Uzaktan eğitimde uzun yıllardır süre gelen önemli eleştirilerden biri, deneyim ve yaparak öğrenmeye dayalı yüz yüze aktivitelerin yerinin doldurulamadığı fikridir. İncelenen araştırmalardan elde edilen bulgular özellikle öğretmenlik, sağlık ve mühendislik alanlarında eğitim alan bireylerin eğitimlerinde uygulama eksikliklerinin daha belirgin olabileceğini işaret etmektedir.

Tablo 12

Uygulama Eksikliğine İlişkin Anatema

Staj ve öğretmenlik deneyimi eksikliği

Uygulamalı derslerin sürdürülmesi ile ilgili yaşanan kısıtlar

Çevrimiçi laboratuvar veya sanal laboratuvar eksiklikleri

Klinik deneyim ve staj eksikliği (sağlık sektörü)

Yaparak öğrenme ve deneyim isteyen mühendislik dersleri için yaşanan sorunlar 


\section{Genel sorunlar}

Araştırma kapsamında incelenen çalışmalarda pandemi dönemi AUE süreçlerine özgü, veya çevrimiçi öğrenmenin teknoloji odaklı yapısından kaynaklanan genel sorun / olumsuzluklar belirlenmiştir. Bu sorunların başında gerekli çevrimiçi pedagoji bilgisi ve teknolojik entegrasyon becerilerine sahip öğretmenlerin yetiştirilmesi konusu gelmektedir. Bunun yanında, mezuniyet tarihlerinin gecikmesi veya ötelenmesi sonucunda bireylerde iş hayatına başlayamama endişesi de oluşmaktadır. Bunlarla birlikte, teknoloji boyutunda, dünya genelinde kitlesel şekilde çevrimiçi araç kullanımı sonucunda yaşanan yoğunluğun yaşattığı bağlantı problemleri ve uyumluluk sorunları öne çıkmaktadır.

Tablo 13. Genel Sorunlar Anateması

Pandemi öncesi dönemde tekno-pedagojik yeterliliğe sahp öğretmen yetiştirme konusunda yaşanan
eksiklikler
Uluslararası öğrenme-öğretme mobilitesinin azalması
Mezuniyet tarihlerinin gecikmesi veya ertelenmesi
Web konferans araçlarına talebin çok artmasıyla zaman zaman yaşanan bağlantı sorunları
Mobil telefonlarla sayfa görüntüleme ve işlevleriyle ilgili uyumluluk sorunu yaşayan öğrenme
yönetim sistemleri
Araştırma projeleri ve desteklenen bilimsel projelerin durması/ertelenmesi
Her cihazda çalışabilen uygulama ve simlasyonlara duyulan ihtiyaç
Öğrenme yönetim sistemlerinin günlük kullanılan araçlar kadar (sosyal ağlar vb.) güçlü arayüzler
sunmaması
Yaşam ortamlarının koşullarından dolayı, veya görünüşlerinden dolayı (hazırlanmak istememe, ev
hali ile sınıfa katılma vb.) öğrenenlerin kameralarını kullanarak etkileşime girmek istememeleri

\section{Tartışma, Sonuç ve Öneriler}

$\mathrm{Bu}$ çalışma COVID-19 pandemi sürecinde gerçekleştirilen AUE faaliyetlerine ilişkin öne çıkan eğitsel kavramlar, yaşanan sorunlar ve eğitsel önerileri küresel düzeyde analiz ederek değerlendirmeyi amaçlamıştır. Araşıtrma kapsamında AUE sürecinde gerçekleştirilen çalışmaların büyük çoğunluğunun yükseköğretim düzeyinde gerçekleştirilmiş olduğu, A.B.D’ nin yayın yoğunluğu açısından diğer ülkelere göre önemli oranda önde olduğu belirlenmiştir. Öne çıkan eğitsel kavramlar, süreçte yaşanan sorunlar ve öneriler incelendiğinde ise farklı kategori ve anatemalar altında spesifik bulgulara ulaşılmıştır.

COVID-19 pandemi döneminde gerçekleştirilmiş AUE algısını içselleştirmiş çalışmalar incelendiğinde, çalışmaların genel olarak var olan durumu tasvir etmeyi, farklı uygulamalarla karşılaştırmayı ve gerçekleştirilen uygulamalarla ilgili yerel/küresel oyuncuları bilgilendirmeyi amaçladığı düşünülebilmektedir. Araştırma kapsamındaki tüm bulgular bütüncül bir bakış açısıyla bir arada değerlendirildiğinde ise, uzaktan eğitim faaliyetlerinin yüksek oranda teknoloji ve dijital beceri temelli olduğu görülebilir.

COVID-19 pandemi dönemindeki AUE süreçleri ise, bu temellerin bir testi niteliğindedir. 2018 PISA raporu, eğitim merkezlerinde görev yapan uzmanların \%30 - \%80 arasındaki bir diliminin dijital araçları öğretime entegre etme becerisine sahip olduğunu işaret etmektedir. Ancak burada önemli nokta, bu oranlar içerisinde \%70 - 80 yeterlilik bandında olan uzmanların Güney Kore, Kuzey Avrupa ülkeleri, Kanada ve ABD gibi gelişmiş ülkelerden olduğudur (UNESCO, 2019, Muñoz-Pérez ve Cubo-Delgado, 2019). Bu bağlamda eğitimcilerin uygulamada teknoloji ve dijital beceri temelli uzaktan eğitim süreçleri konusunda zorlanabileceği öngörülebilir. Bunun yanında birçok eğitimci ve öğrenenin, COVID-19 pandemisine kadar, çevrimiçi öğrenmeyi uygulamada hiç deneyimlememiş oldukları (de Jong, 2020), ve geleneksel öğretmen eğitiminin çevrimiçi pedagoji ve yeterlilikler bağlamında yetersiz olduğu da öne sürülebilir. Dolayısıyla pandemi ile birlikte başlayan süreçte özellikle öğretmen eğitiminde bir dönüşüme gidilmesi gerekliliği ön plana çıkmıştır. 
Araştırmayla ilgili bir diğer öne çıkan / üzerinde durulması gereken konu ise farklı eğitim kurumlarının uzaktan eğitim faaliyetlerine ilişkin belirgin politika ve yol haritalarının olmadığının raporlanması ve bu doğrultuda ilgili politikaların oluşturulması/işe koşulması gerekliliğinin dişa vurumudur. Bu politikalar ulusal düzeyden başlanarak küresel düzeye doğru yapılandırılmalıdır. Bu yapılandırmaya bağlı olarak yerel teknoloji alt yapılarının geliştirilmesi de hızlandırılacaktır.

The World Bank / Education Global Practice raporu (2020), pandemi döneminde gerçekleştirilen okul ertelemelerinin ve çeşitli eğitim kurumlarının yüz yüze eğitim iptallerinin artmasının uzun vadede ekonomik sıkıntılara neden olabilecek öğrenme kayıplarıyla sonuçlanabileceğini ifade etmiştir. Bu öngörü oldukça karamsar bir tabloyu yansıtmaktadır. Bu karamsar tablo pandemi dönemi ve sonrası eğitsel faaliyetlerinin, AUE sürecinden elde edilen deneyimlerle iyileştirilmesi ve yeni bir bakış açısı kazanılmasıyla iyimser bir tabloya dünüştürülebilir. Bu araştırmada öne çıkan önerilere ek olarak alanyazında pandemi dönemi pedagojisinin doğru anlaşılarak fırsata çevrilmesi, birçok pozitif eğitsel anlayış farklılı̆̆ını ve eğitsel inovasyonu da beraberinde getirebilecektir (Bozkurt ve Sharma, 2020, Bozkurt vd., 2020).

Pandemi dönemi acil uzaktan öğretim faaliyetlerinde olumsuz etkileriyle ilk sırada yer alan kavram dijital uçurum/bölünme kavramıdır. Bu çalışmada incelen araştırmaların büyük çoğunluğunda dijital bölünme tecrübelerine dayalı zorluklar raporlanmıştır. Buna ek olarak farklı çalışmalarda raporlanan teknofobi ve 21. yüzyıl teknolojik beceri yetersizlikleri de bu çalışmada öne çıkan olumsuz teknoloji bağlamlı durumlara vurgu yapmaktadır (Alvarez, 2020; Lynch, 2020). Bu durum uzaktan eğitim alanındaki tüm paydaşları, "önce pedagoji sonra teknoloji" anlayışı yerine, "önce teknoloji sonra uygun pedagojik yaklaşımın harmanlaması" anlayışına itebilir. Bu yönelim eğitim ekosistemlerinde teknoloji pedagoji ilişkisinin yeniden sorgulanması konusunda bir yönelimi işaret eder.

Pandemi dönemi araştırmalarında Zimmerman (2020), koronavirüsü "büyük bir çevrimiçi öğrenme deneyi" olarak tanımlamıştır. Bu araştırma kapsamında incelenen çalışmalara bütüncül bir bakış açısıyla bakıldığında, Zimmerman' in tanımının problematik bir tanım olduğu söylenebilir. AUE döneminde gerçekleştirilen eğitsel faaliyetler çoğu zaman, kısıtlı sürelerde hazırlanan ve öğrenenlerin öğrenme içerikleriyle bir araya getirilmesini amaçlayan faaliyetlerdir. Bu bağlamda oluşturulan AUE süreçlerinde yaşanan öğrenme deneyimlerinin ideal olduğunu iddia etmek, bunun yanında bu süreçleri önceki yüz yüze süreçlerle karşılaştırmak oldukça zorlayıcı olabilir. Bu süreçlerde öğrenmeye ilişkin herhangi bir değişkenin etkisinin incelenmesi de çok sağlıklı olmayacaktır. Ancak bu dönemde çevrimiçi derslere devam konusunda öğrenenlerin genellikle sürece devamlarının zorunlu tutulması, araştırılması ve üzerinde durulması gereken (uzaktan eğitim felsefesine aykırılık bağlamında) önemli konulardandır.

Araştırma kapsamında içerik analizine dahil edilen/incelenen çalışmalardan elde edilen edilen bulgular sentezlenerek, pandemi dönemi ve sonrası planlı uzaktan eğitim faaliyetleri için aşağıda çeşitli öneriler sunulmaktadır. Bu bölümde sunulan öneriler, üçüncü araşturma sorusunun bulgularını ve aynı zamanda buna bağlı olarak araştırmanın bütünsel sonuçlarına ilişkin önerileri de yansıtmaktadır. Öneriler, kolay takip edilebilmeleri için basitçe kategorilendirilerek listelenmiştir.

\section{Dijital Uçurumu Engelleme Çabası}

- İnternet altyapı çalışmalarının özellikle az gelişmiş veya gelişmekte olan ülkelerde hızlı bir şekilde geliştirilmesi

- "Herkes için teknoloji hareketi” nin düşük gelir gruplu aileler için bedava veya düşük ücretli bilgisayar sağlamak için kullanılması

- Kırsal kesimlerde internet alt yapısının güçlendirilmesi

- Daha düşük donanım ve düşük bant genişliğinde çalışabilecek optimal çevrimiçi araç ve etkinlikler planlanmasi

- Öğrenenlerin erişimlerinin, bilişsel sorun yada özel gereksinimlerine göre planlanması 


\section{Kurumsal Eylem Planı}

- Eğitim kurumlarında öğrenme tasarımı ve dijital içerik üretim ve denetim birimlerinin kurulması

- Eşzamansız video içerik sürelerini öğrenen özelliklerini dikkate alarak münkün olduğunca kısa tutulmasi

- Kaliteli görüntü ve ses içeriği için öğreticilere rehberlik sunulması ve gerektiğinde kurumsal olarak donanım-yazılım desteği sağlanması

- Mezuniyet, konser, kutlama ve benzeri sanal etkinlikler oluşturma konusunda kurumsal birim kurulması

- Staj ve öğretmenlik deneyimi, çeşitli uygulamalı derslerin sürdürülmesi, sanal laboratuvar hazırlıkları, klinik deneyim ve staj yönergelerinin kurumsal olarak önceden tespit edilmesi

- Eğitim kurumları, akademisyenler, öğretmenler veya çeşitli eğitmenlerin bireysel bilgi ve becerilerini desteklemek, profesyonel gelişim ağları kurmak, aileler ile birlikte geniş okul toplulukları kurmak, öğretmenlere bu yapıda karar verici ve iletişim kurucu rollerini atamak gibi misyonların tanımlanması

- Özellikle öğretmen eğitiminde çevrimiçi öğrenmenin bileşenleri iyi anlatılarak bu konuda bir politika oluşturulması

- Açık kaynak kodlu ulusal web konferans konferans sistemlerinin geliştirilerek kurumsal entegre edilmesi

\section{Öğretim-Öğrenme Etkinlikleri ve Planlaması}

- Eşzamanlı ders katılımlarından ziyade eşzamansız katılımı destekleyebilecek etkinlikler tasarlanması. Esneklik sürdürülebilirlik için oldukça önemli bir bileşen, bu bağlamda çevrimiçi ders süreçlerinde tam yapilandırma olmaması

- Eşzamansız aktivitelere ağırlık verilmeli ve öğrenen haftalık yükünü çok arttırmayacak şekilde çeşitlendirilmesi

- Eşzamanlı derslerin kayıtları mutlaka erişilebilir olması

- Modüller ders yapısı geliştirilerek öğrenme hedefleriyle eşleştirilmesi

- Spesifik yönergeler ve açı beklentiler ile bilişsel bulunuşluk sağlanmaya çalışılması

- Öğrenenlere ne öğrendiniz neyi öğrenmek istersiniz sorularının yöneltilmesi

- Ders konularının kısa kısa konular halinde parçalanması

- Sık sık kısa sınav ve öğrenme aktivitelerinin kullanması

- Canlı derslerin öğrenenlerin soru sorup cevap alabilecekleri, dahası toplu tartışmalar yürütülebilecekleri bir yapıya büründürülmesi

- Eşzamanlı buluşmaların herkesin görüntülü olarak katılabileceği şekilde düzenlenmesi ve buluşmaların katılımcı gruplarına bölünmesi

- Grup projeleri tanımlanması

- Dersin-sürecin başında beklenen çıktıların net olarak tanımlanması

- Öğrenenlere düzenli geri bildirim verilmesi

- Çevrimiçi öğretim hem öğreticiler hem de öğrenenler için oldukça zaman alıcı olup, bu doğrultuda etkinlik ve ödev dozunun iyi ayarlanması

- Öğrenenlerin kendilerini daha net olarak ifade edebilmesi veya farklı alanlarda performans kayıtları için kendilerinin üreteceği eşzamansız videoların kullanılması 


\section{Ölçme Değerlendirme}

- Alt yaş gruplarında not vermeme / genel olarak yalnızca geçti / kaldı / tamamlanmadı şeklinde değerlendirmede bulunulması, ancak sürekli olarak öğrenen performanslarılla ilgili geribildirim verilmesi

- Çevrimiçi sınavlarda gerekli durumlarda hile engelleme yazılımlarının (fraud prevention softwares) kurumsal olarak kullanılması

- Öğrenenlere hatalı yaptıkları bir ödev veya sınav için tekrar hak verilmesi

\section{Destek}

- Öğretmenlerin arasında yada öğretmen eğitimine webinarları bir norm haline getirme

- Harmanlanmış öğrenme, dönüştürülmüşs sınıf gibi yaklaşımlarla ilgili öğreticilerin bilgilendirilmesi

- Akademisyenler arasında destek gruplarının oluşturulması

- Ebeveynler için sosyal ve duygusal terapi gruplarının oluşturulması

- Öğrenenlerin aktif birer kendi kendine öğrenen olmalarının sağlanmaya çalışılması

- Öğrenenlere faydalı buldukları içerikler / karşılaştıkları sorunlarla ilgili çözüm basamaklarını, diğer öğrenenler ve öğreticelerle paylaşabilmeleri konusunda destek olunması

- Teknik sorunlar konusunda hazırlıklı olmak gerektiğinde bu konuda bir destek kişisinin belirlenmesi

- Çeşitli açı eğitsel kaynaklar konusunda öğrenenlerin bilgilendirmesi

\section{Uygulama Dersleri}

- Öğrenenlerle gerçekleştirilen anlık bireysel sağlık/ihtiyaç bildirimleri (check-ins) öğrencilere bir topluluğa ait olma duygusunu aşllayabilir.

- Çevrimiçi tartışmalar ve akran gerbildirimi özellikle sosyal bulunuşluluk için oldukça önemli

- Sorgu toplulukları yaklaşımı pandemi dönemi çevrimiçi eğitim faaliyetleri için oldukça önemli

- Laboratuvar ortamlarının dersin hocası tarafından video anlatımla sağlanması, gerçek bir deneye oranla daha verimli sınıf süresi sağlayabilir. Böylelikle laboratuvar öğrenmesini çevreleyen daha geniş kavramlar ve hedeflerine odaklanılabilir.

COVID-19 krizinden sonra dünyada eğitsel faaliyetlerin, günlük yaşamın diğer unsurları gibi değişime uğrayacağı düşünülmekle birlikte, bu değişimin ne yönde olacağına ilişkin kesin yargılarda bulunulamamaktadır. COVID-19 tarihteki ilk pandemi olmamakla birlikte son pandemi de olmayacaktır. Bununla beraber değişen iklim koşulları veya savaş gibi nedenler de, gelecekte yüz yüze eğitim faaliyetlerinin aksamasına neden olabilecek etkenlerdir. Pandemi dönemi sonrasında geleneksel yüz yüze eğitime tamamen geri mi dönülecek, yoksa pandemi dönemi acil uzaktan süreçlerinde yaşanan sorun ve dönemsel travmanın zihinlere kazınması sonucu uzaktan eğitimin yalnızca gerekli durumlarda kullanılacak bir alternatif olarak düşünülmeye devam mı edilecek? (Kerres, 2020). Bu soruların cevapları henüz yanıtlanamasa da pandemi dönemindeki travma ve yıkımın yükseköğretimde inovatif hareketlere sebep olabileceği unutulmamalıdır. Pandemiler tarih boyunca insanların geçmişi bütünüyle geride bırakarak geleceği yeniden hayal etmelerine sebep olmuştur (Peters ve diğerleri, 2020). Bu doğrultuda pandemi döneminde gerçekleştirilen araştırmaların detaylı şekilde incelenerek, pandemi dönemi eğitim pedagojisini doğru anlamak ve çevrimiçi öğrenmenin yapıcı etkilerine odaklanmak en doğru yaklaşım olacaktır. 


\section{Kaynakça}

Alvarez, A. J. (2020). The phenomenon of learning at a distance through emergency remote teaching amidst the pandemic crisis. Asian Journal of Distance Education, 15(1), 144-153. https://doi.org/10.5281/zenodo.3881529

Bozkurt, A., Jung, I., Xiao, J., Vladimirschi, V., Schuwer, R., Egorov, G., .. \& Paskevicius, M. (2020). A global outlook to the interruption of education due to COVID-19 Pandemic: Navigating in a time of uncertainty and crisis.(2020). Asian Journal of Distance Education, 15(1), 1-126. https://doi.org/10.5281/zenodo.3878572

Bozkurt, A., \& Sharma, R. C. (2020). Emergency remote teaching in a time of global crisis due to CoronaVirus pandemic. Asian Journal of Distance Education, 15(1), 1-6. https://doi.org/10.5281/zenodo.3778083

Braun, V., \& Clarke, V. (2006). Using thematic analysis in psychology. Qualitative research in psychology, 3(2), 77-101. https://doi.org/10.1191/1478088706qp063oa

Clapton, J., Rutter, D., \& Sharif, N. (2009). SCIE systematic mapping guidance. Erişim adresi: http://www.scie.org.uk/publications/researchresources/rr03.pdf

de Jong, P.G.(2020). Impact of moving to online learning on the way educators teach. Medical Science Educator, 30(3), 1003-1004. https://doi.org/10.1007/s40670-020-01027-7

Denyer, D., \& Tranfield, D. (2009). Producing a systematic review. In D. A. Buchanan \& A. Bryman (Eds.), The Sage handbook of organizational research methods (pp. 671-689). Sage Publications Ltd.

Dünya Bankası (2017). Higher Education. Erişim adresi: https://www.worldbank.org/en/topic/tertiaryeducation

Dünya Sağllk Örgütü. (2020). Coronavirus disease (COVID-19) pandemic. Erişim adresi: https://www.euro.who.int/en/health-topics/health-emergencies/coronavirus-covid-19/novelcoronavirus-2019-ncov

Fakhruddin, B. S., Blanchard, K., \& Ragupathy, D. (2020). Are we there yet? The transition from response to recovery for the COVID-19 pandemic. Progress in Disaster Science, 7, 100102. https://doi.org/10.1016/j.pdisas.2020.100102

Grant, M. J., \& Booth, A. (2009). A typology of reviews: an analysis of 14 review types and associated methodologies. Health Information \& Libraries Journal, 26(2), 91-108. https://doi.org/10.1111/j.14711842.2009.00848.x

Hodges, C., Moore, S., Lockee, B., Trust, T., \& Bond, A. (2020). The difference between emergency remote teaching and online learning. EDUCAUSE Review, 27, 1-12. Erişim adresi: https://er.educause.edu/articles/2020/3/the-difference-between-emergency-remote-teaching-andonline-learning

Houlden, S., \& Veletsianos, G. (2020). The problem with flexible learning: Neoliberalism, freedom, and learner subjectivities. Learning, Media and Technology. Çevrimiçi ön yayın. https://doi.org/10.1080/17439884.2020.1833920

Hsieh, H. F., \& Shannon, S. E. (2005). Three approaches to qualitative content analysis. Qualitative Health Research, 15(9), 1277-1288. https://doi.org/10.1177/1049732305276687

Kerres, M. (2020). Against all odds: Education in Germany coping with Covid-19. Postdigital Science and Education, 2(3), 690-694. https://doi.org/10.1007/s42438-020-00130-7 
Khan, H., Vasilescu, L. G., \& Khan, A. (2008). Disaster management cycle-a theoretical approach. Journal of Management and Marketing, 6(1), 43-50. Erişim adresi: http://mnmk.ro/en/documents/2008/20086.pdf

Krippendorff, K. (2004). Reliability in content analysis: Some common misconceptions and recommendations. Human communication research, 30(3), 411-433. https://doi.org/10.1111/j.14682958.2004.tb00738.x

Landis, J. R., \& Koch, G. G. (1977). The measurement of observer agreement for categorical data. Biometrics, 33(1), 159-174. https://doi.org/10.2307/2529310

Loffe, H. \& Yardley, L. (2004). Content and thematic analysis. In D.F Marks \& L. Yardley (Eds.). Research Methods for Clinical and Health Psychology (1st ed) (pp.56-69). London: Sage.

Lynch, M. (2020). E-Learning during a global pandemic. Asian Journal of Distance Education, 15(1), 189-195. https://doi.org/10.5281/zenodo.3881785

Muñoz-Pérez, E. \& Cubo-Delgado, S. (2019). Digital competence, special education teachers' training and attitude towards the ICT. Profesorado, Revista de Currículum y Formación del Profesorado, 23(1), 209241. https://doi.org/10.1109/RITA.2020.3033207

Naidu, S. (2017). How flexible is flexible learning, who is to decide and what are its implications?. Distance Education, 38(3), 269-272. https://doi.org/10.1080/01587919.2017.1371831.

Peters, B. C. M., \& Wood, W. (2017). Autism and equine-assisted interventions: A systematic mapping review. Journal of autism and developmental disorders, 47(10), 3220-3242. https://doi.org/10.1007/s10803-017-3219-9

Peters, M. A., Rizvi, F., McCulloch, G., Gibbs, P., Gorur, R., Hong, M., ... \& Quay, J. (2020). Reimagining the new pedagogical possibilities for universities post-Covid-19: An EPAT collective project. Educational Philosophy and Theory. Çevrimiçi ön yayın. https://doi.org/10.1080/00131857.2020.1777655

Petticrew, M., \& Roberts, H. (2008). Systematic reviews in the social sciences: A practical guide. Hoboken, NJ: John Wiley \& Sons.

Sangster, A., Stoner, G., \& Flood, B. (2020). Insights into accounting education in a COVID-19 world. Accounting Education, 29(5), 431-562 https://doi.org/10.1080/09639284.2020.1808487

Strauss, A., \& Corbin, J. (2008). Basics of qualitative research: Grounded theory procedures and techniques. Thousand Oaks, CA: Sage

World Bank (2020). Guidance Note on Remote Learning and COVID-19. Washington, D.C. World Bank Group. Erişim adresi: http://documents.worldbank.org/curated/en/531681585957264427/GuidanceNote-onRemote-Learning-and-COVID-19

UNESCO (2020a). COVID-19 Educational Disruption and Response. Erişim adresi: https://en.unesco.org/covid19/educationresponse

UNICEF (2020b). Leaving No Child behind during the Pandemic: Children with Disabilities and COVID-19. Erişim adresi: https://data.unicef.org/topic/child-disability/covid-19/

UNESCO (2019). Migration, Displacement \& Education: Building Bridges, Not Walls. Erişim adresi: https://en.unesco.org/gem-report/report/2019/migration

United Nations Development Programme (2020). Human Development Report. Erişim adresi: http://hdr.undp.org/sites/default/files/hdr2020.pdf 
Warschauer, M. (2004). Technology and social inclusion: Rethinking the digital divide. Cambridge: MIT press.

Zimmerman, J. (2020). Coronavirus and the Great Online-Learning Experiment. The Chronicle of Higher Education. Erişim adresi: https://www.chronicle.com/article/Coronavirusthe-Great/248216

\section{Extended Abstract}

\section{Purpose}

With the closure of educational institutions, social distance rules and changing personal/social sensitivities, the form of education, which is conceptualized as emergency remote education, has become the dominant form of education all over the world. Educational processes that can also be encountered as emergency remote teaching or emergency remote learning have been implemented quickly all over the world using the necessary communication tools. The main goal in this process was to create an immediate alternative to failing educational activities. This alternative was actually the reflex of quickly combining tutorials and learners with the help of a variety of online technologies. In other words, this process can be considered as a repair process that offers educationally "manageable" experiences, although not ideal when considering planned remote educational processes (Hodges et al, 2020). This study primarily aims to monitor/evaluate related constraints or examples in a local and global context by uncovering problems and good examples of emergency remote education activities in pandemic at a global level. Accordingly, the main objective of the research is to provide thematic/categorized solution proposals for planned distance education activities to be carried out during or after pandemic, using the findings obtained. Within the scope of the research, answers to the following research questions were sought.

1. What are the educational concepts that stand out in the emergency remote education process?

2. What are the negative situations in the emergency remote education process and the issues that await resolution?

3. What are the recommendations of researchers regarding distance learning for the aftermath of the emergency remote learning process?

\section{Design and Methodology}

This study is a systematic mapping study of emergency remote studies carried out during the Covid-19 pandemic. Within the scope of the research, scientific articles, full-text papers and research reports were used. Gray literature was also used in the interpretation of data. Studies analyzed in the study were collected through academic databases as follows; SCOPUS, Web of Science, Science Direct, Emerald Insight, IEEEXplore, ACM Digital Library, EBSCO host research databases (Academic Search Premier, H.W. Wilson, British Education Index, ERIC et al.), JSTOR and Google Scholar (Table 1). Research in related databases was carried out through the "emergency remote AND (education OR teaching OR instruction OR learning) inquiry and Boolean operators. Thematic analysis of the data and descriptive analysis were used where possible. A total of 252 studies were included in the initial analysis and 152 studies were analyzed in the final case when non-subject area studies were excluded.

\section{Findings}

After the descriptive and thematic analysis carried out in the study, based on research questions, pandemicera distance learning experiences were examined in the main categories as follows; "featured concepts", "problems", and "recommendations". In this, some simple descriptive data is also presented (audience, featured 
countries). From the findings, "featured educational concepts" are examined in 5 categories, and problems/negativity are listed under 11 main themes. Within the scope of the research, it was observed that the studies carried out during the pandemic emergency remote teaching period were mostly carried out at the higher education level (66.29\%). With the evaluation of teacher educators (11.24\%) in the context of higher education, studies on the education experiences of the K-12 level (12.36\%) and the in-service teachers (8.99\%) who took part at this level remained a minority.

When pandemic-era emergency remote studies were examined in the context of the country in which the publication was carried out, it was seen that the studies were concentrated in countries where the United States, Canada, Philippines, The United Kingdom and Germany were the heads. Generally, it can be commented that developed countries want to preserve the sustainable structures of national education processes by revealing different perspectives on the emergency remote teaching process.

Educational concepts that stand out during the emergency remote education period are examined in 5 main categories: "Learning teaching processes and approaches", "process design", "learner-teaching features \& learning variables", "corporate policies", and "other". When the concepts that stand out are examined, it is noticeable that the use of flexible learning, hybrid learning and Hyflex learning concepts increases especially in the process that begins with urgent distance learning activities.

Problems and limitations experienced during the emergency remote education process were revealed in 79 items under 11 main themes. These themes are listed as follows; "digital divide", "techno-pedagogical inexperience \& negativity related to online learning", "content design quality", "distance education management", "economic difficulties", "independent learning skills and work environment", "support, pandemic psychology", "health and familial constraints", "data security", "lack of application" and "general problems".

\section{Research Limitations}

The first and most important limitations of this study is that the work was included only a partial data set. Only studies on ERE processes are included in the research. This is due to the nearly 20,000 studies involving Covid19 pandemic education processes. This number, thematically, is very difficult to perform the analysis of the studies carried out during this period. In this context, it was appropriate to put forward a partial map from the studies that correctly describe the COVID-19 process distance education activities as AUE. However, the research is limited to the scientific articles, papers and book chapters published in academic journals. Also, gray literature is used in the interpretation phase, these studies are not included in the analysis. Another limitation found in such research is the process of thematic content analysis regarding the nature of qualitative research. Coefficients obtained when coder reliability is calculated may not mean that all codes are created objectively (Loffe \& Yardley, 2004). From this point of view, the quality of the findings can be evaluated with new and different predictions that can contribute to the subject presented and studied by the research (Krippendorff, 2004).

\section{Implications (Theoretical, Practical and Social)}

In this study, some implication recommendations regarding the use of educational experiences obtained in emergency remote education processes for the development of online learning activities were presented. These recommendations are grouped into six different categories: effort to avoid the digital divide, corporate action plan, teaching-learning activities and planning, assessment, support, and applied courses.

Among the categories, teaching-learning activities and corporate action plan categories stand out in terms of the variety of recommendations they include. When the proposed teaching-learning activities were examined, 
it was observed that the recommendations were usually shaped around arguments such as the level of structure of online courses, feedback, providing frequent and short-term activities. In the corporate action plan proposal category, proposals related to digital content production, solution of connectivity problems, social activities and in-service training came to the fore. Other categories of recommendations consist of strategies for reducing the digital divide, strategies for evaluating learning, measures to be taken regarding the processing of applied courses, and recommendations for supporting learners in different ways in the face of all kinds of traumas and constraints.

It is believed that the 43 different proposals put forward for the application, as well as the problems and prominent concepts examined under different themes and categories, will contribute to the emergency remote education processes from a different perspective.

\section{Originality/Value}

As mentioned earlier, this study aims to expose the problems and solutions experienced in the emergency remote education process in a global context. When the educational concepts, problems and recommendations experienced in the process were examined, specific findings were reached under different categories and themes. These findings are thought to give researchers, experts and teachers different perspectives during and after the emergency remote education process.

Pandemics have historically caused people to reimagine the future by leaving the past completely behind (Peters et al., 2020). Accordingly, it would be the right approach to examine the researches carried out during the pandemic period in detail, to understand the educational pedagogy of the pandemic period correctly and to focus on the constructive effects of online learning.

Araştırmacı Katkısı: Sezan SEZGİN (\%100). 